This is the version of the article that was accepted for publication in Managerial Auditing Journal, all rights reserved.

Ella Desmedt, Danielle Morin, Valérie Pattyn and Marleen Brans (2017). Impact of performance audit on the Administration: a Belgian study (2005-2010). Managerial Auditing Journal 2017 32:3, 251-275

http://www.emeraldinsight.com/doi/full/10.1108/MAJ-04-2016-1368

\title{
Impact of performance audit on the Administration: A Belgian study (2005-2010)
}

\begin{abstract}
Purpose -This study of the impact of Belgian Court of Audit on the federal Administration for the 2005 to 2010 period aims to highlight the auditors' influence on the management of governmental organizations through the performance audits they have been conducting since 1998. A set of ten variables allows us to measure the three types of uses of performance auditors' work by auditees: instrumental, conceptual and strategic uses.

Design/methodology/approach - A survey was sent out to a total of 148 respondents identified by the authorities of the targeted organizations. 47 usable questionnaires were completed (32\% response rate).

Findings - The Court of Audit's impact on the audited entities did not provoke radical changes in the auditees' organizational life but the intervention of the auditors was nevertheless noticeable. The nature of the impact was rather conceptual than strategic or instrumental. And the negative consequences on auditees anticipated in the literature were not observed.

Research limitations/implications - Given the five-year period covered by the study which was made in 2014 (four years after 2010), it had to deal with the mortality of respondents and the loss of organizational memory.

Practical implications - The study gives more accurate insights about the influence that Supreme Audit Institutions actually exert on audited Administrations through their performance audits.

Originality/value - Since Supreme Audit Institutions have been mandated to evaluate government's economy, efficiency and effectiveness for almost 40 years in the western democracies, it is mandatory that their actual ability to influence Administrations be documented more abundantly and independently by academic researchers.
\end{abstract}


Keywords: Supreme Audit Institutions - Performance audit - Administration - Court of Audit

Article Type: Research paper 


\section{Impact of performance audit on the Administration: \\ A Belgian study (2005-2010)}

\section{Introduction}

As of 1998, the conduct of performance audits has become an integral part of the Belgian Court of Audit's portfolio, and a valuable addition to the Court's activities in financial audits and regularity audits. By conducting performance audits, the Belgian Court of Audit follows common practice of many Supreme Audit Institutions (SAIs) in the OECD area. Irrespective the particular terminology applied within a specific country (for instance: 'contrôle de la bonne gestion', 'value for money audits'), performance audits concern the assessment of government management in terms of the so-called three E's: economy, efficiency and effectiveness. With new competencies on the agenda, the mandate of many SAIs has been reformulated in a more encompassing way, in the previous two decades. Traditionally, the role of the SAIs was commonly denoted as 'watchdogs', i.e. assisting parliamentary assemblies in exercising their supervising function as regards collecting and spending of public funds (Sterck, 2007; Van Loocke \& Put, 2010). Nowadays, some Supreme Audit Institutions have endorsed the role of 'advisors', charged with the explicit task to contribute to an improvement of public management. The Belgian Court of Audit upholds this double mission (Rekenhof, 2004: $1)$.

Having impact is hence the common rationale of these "watchdogs" who want to influence the entities audited and expect their recommendations to be implemented. This ambition is likely to have an impact on the SAIs' auditing process: from selecting audit topics, planning the work, to drafting audit reports (Lonsdale, 1999). Impact is also a leitmotif in the professional standards developed by the International Organization of Supreme Audit Institutions (INTOSAI, 2013), as can be derived from the following excerpts:

The main objective of performance auditing is constructively to promote economical, effective and efficient governance (p.13)

The topic selection process should aim to maximize the expected impact of the audit while taking account of audit capacities (p.13) 
The report should explain why and how problems noted in the findings hamper performance in order to encourage the audited entity or report user to initiate corrective action (p.16)

The question can yet be raised whether these high ambitions are actually realized in practice. In this article we empirically address this puzzle, by a systematic study of the impact of the audits conducted by the Belgian Court of Audit within the federal administration in the period 2005-2010. We present the results of a survey that has been previously conducted in a Canadian context (Morin, 2008, 2014). Based on the survey findings, we will answer the following two questions, both approached from the auditees' standpoint:

1. What has been the impact of the performance audits on the management of audited entities in the Belgian federal administration?

2. Which factors have contributed to this impact if any?

With this survey, we aim to meet three objectives of theoretical, empirical and normative value: First, we assess the assumption raised by several scholars (Power, 1997; Leeuw, 2006; Lonsdale, 1999) that the potential impact of SAIs is often overestimated. SAIs often implicitly apply a mechanistic feedback theory, which does not always match the complex audit reality. In the Canadian setting (Morin, 2008, 2014), this assumption could not be discredited. Overall, the impact of the Auditor General (which is the appellation for the Canadian Supreme Audit Institution (SAI)) proved to be generally limited. The question is, though, whether this pessimistic assumption also applies to the Belgian Court, which is in contrast to the Canadian Westminster-style SAI a case of the Napoleonic family of SAIs.

Secondly, the study is also practically relevant for the work of the SAIs' auditors who are required to monitor the impact of their recommendations, in compliance with the INTOSAI standards. This study complements SAIs' anecdotal evidence with more systematic data, at least for the Belgian federal case. We trust that the method used and findings are inspirational for SAIs to set up a more systematic monitoring system of their impact on audited Administrations. 
Third, a study about the impact of performance audits has important normative value. Having impact is essential for the legitimacy of Supreme Audit Institutions' auditors vis$\grave{a}$-vis auditees and vis-à-vis the tax-payers (Lonsdale, 1999; Van Loocke, 2013). We believe that Morin's (2001) claim (115-116) is still valid: “Time is up for certain political institutions which have been considered sacred cows, above attack and unimpeachable in their effectiveness. The Auditors General offices should not be above the questions which have been aimed at most of the other public institutions".

The article is structured as follows: First we present the conceptual framework that supports our investigation of SAIs' impact on Administrations through their performance audits. After introducing the Belgian Court of Audit's context, we explain the variables tested and the methodology to do so. We then present the results of the survey followed by a discussion and a conclusion about the Court's impact on Belgian federal Administration for the performance audits conducted during the period 2005-2010.

\section{Investigating impact: our conceptual and theoretical stance}

\section{Unraveling impact in different types}

Investigating Supreme Audit Institutions' impact is a challenging undertaking because of the conceptual confusion that surrounds the notion. In this article, we subscribe to Lonsdale's conception of SAIs' impact through performance audits (1999: 171):

By impact we mean primarily the direct and indirect effect or influence that a Supreme Audit Institution (SAI) can have on the practices, performance and culture of the audited entity as a result of its performance audit work. Impact may arise from recommendations made by the SAI which result in the strengthening of weak administrative procedures and practices or lead to financial savings. Alternatively, it may involve influencing, or, in some cases, instigating debate on a particular subject. And, lest we assume that SAIs can have impact only when they bring about change, we should not also forget the reinforcement value of positive assurance provided by performance auditors where they find good practice.

Lonsdale emphasizes the various forms that SAIs' impact can take. In accordance with the literature about the utilization, influence and impact of policy evaluations (Pollitt, 
2006; Weets, 2001), three types of SAIs' impact have been identified: instrumental, conceptual and strategic uses (Cummings, 2002; Kirkhart, 2000; Widmer \& Neuenschwander, 2004).

Instrumental use refers to performance audits influencing policy decisions or contributing to solve specific problems. The auditors' recommendations are then supposed to lead to immediate and visible actions taken by auditees. This type of use reflects a linear idea of impact which is predominantly present among many courts of audit. The will to improve the functioning of governments by means of performance audits is an idea present in the mission statement of pretty many Supreme Audit Institutions in western countries (Van Loocke and Put, 2010, 2011; Morin and Hazgui, 2016).

Conceptual use is mostly associated with Carol Weiss' (1977) notion of the 'enlightenment' input of audits or evaluations. Auditors' reports can then help to better understand a specific policy measure, or the causal mechanisms of a potential dysfunction. In this perspective, the impact is conceived as cognitive and will not necessarily be translated in visible or tangible changes. Strategic use, also coined persuasive or symbolic use, implies SAIs' reports being instrumentalized to feed the political debate.

The various types of impact are not mutually exclusive. One single audit can simultaneously serve multiple types of use. Conceptual use, though, usually precedes the other types (Cummings, 2002). Some authors (Widmer and Neuenschwander, 2004 for example) further distinguish between interactive use (procedural use by different stakeholders), political-legitimizing use (ex post justifying certain decisions), and tactical use (winning time). For our study, we have focused on the three most frequently functions which are acknowledged for performance audits.

A comprehensive understanding of impact also requires taking into account the time frame for the impact to be manifested. Kirkhart (2000) made a substantial theoretical contribution in this regard. 'Immediate' impact occurs during the actual planning and 
implementation of the audit or evaluation. 'End of cycle' influence coincides with the conclusion of the evaluation process. 'Long term' impact refers to the use of auditors' findings and recommendations in a near future, but not necessarily immediately after their audit. We follow Kirkhart in stating that the time frame should be conceived independently of the earlier mentioned types of use: instrumental use is not necessary apparent in the short term, and conceptual use should not be strictly associated with long term use. Lonsdale (1999) furthermore states that the existence of performance audits as such can have a deterrent effect which notably entails discouraging 'bad practice'. In Kirkhart's time frame perspective, this type of use would be labeled as 'preventive' use.

\section{Factors influencing SAIs' impact on Administrations through performance audits}

In 2016, academic research about SAIs' impact on Administrations through their performance audits is still very scarce. In 2010, Van Loocke and Put, both working at the Belgian Court, made an extensive international literature review of empirical studies about this SAIs' impact. They inventoried fourteen empirical studies. Systematic comparison of these studies was difficult since they varied substantially in research questions, scope, concepts, etc. Since 2010, several new studies have been published about SAIs' impact (Kells and Hodge, 2011; Morin, 2014; Nurul, Athira Abd Manaf, 2010; Raudla et al., 2015; Reichborn-Kjennerud, 2010; Van Acker et al., 2014). The major findings of these studies are generally in line with their predecessors. On the basis of their review, Van Loocke and Put $(2010,2011)$ compiled a comprehensive overview of factors that return in the literature as potentially influencing the impact of performance audits. The factors are ordered in a theoretical model, composed of three clusters: factors situated at micro-level (i.e. related to the audit itself); factors at meso-level (concerning the SAIs and the entity audited); and factors at macro level (relating to the public sector). It would exceed the scope of this article to extensively introduce each of these factors. The figure 1 summarizes all factors that might influence the impact of performance audits conducted by SAIs.

\section{Figure 1}




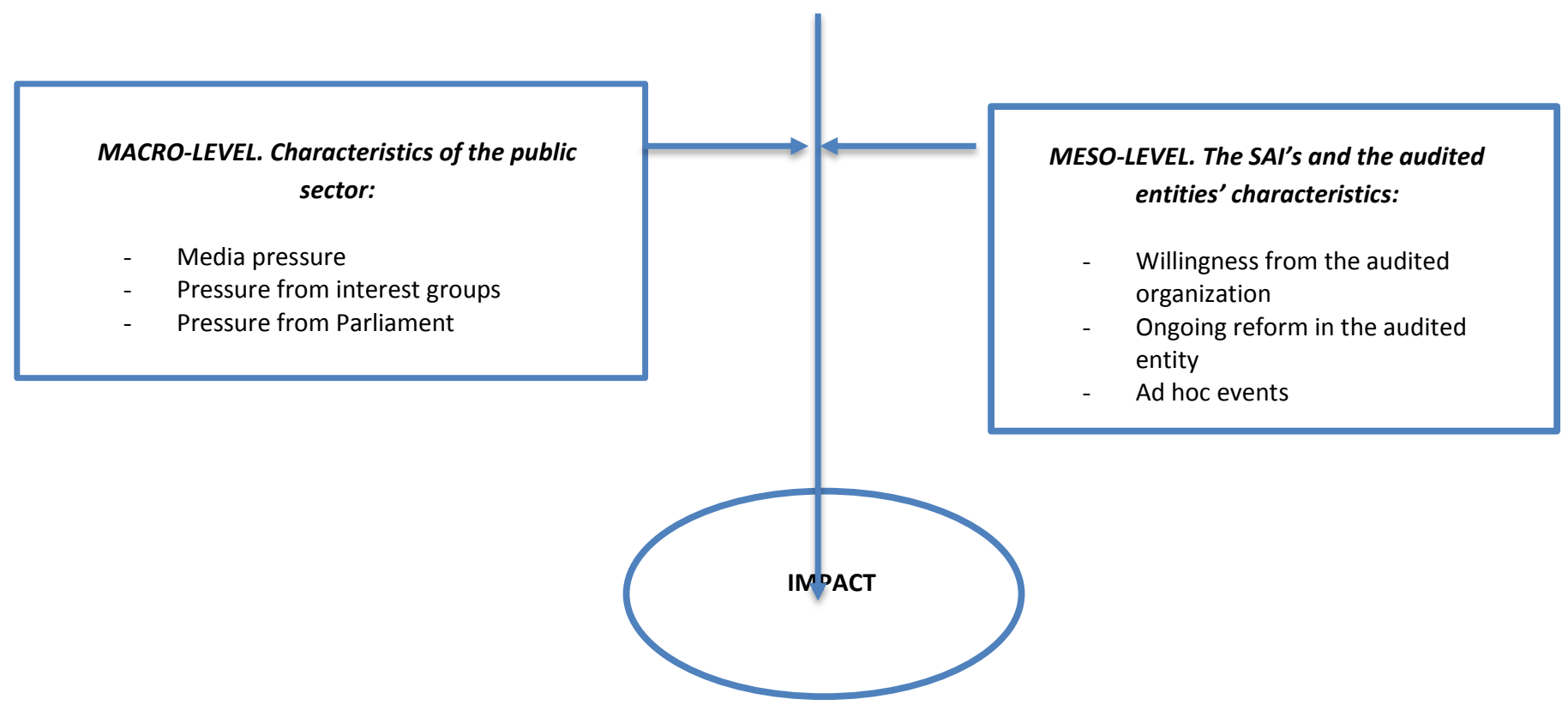

Source: Van Loocke and Put (2010, 2011)

As far as the methodology is concerned, no less than one third of the available studies identified by Van Loocke and Put $(2010,2011)$ simply use the percentage of implemented recommendations as an impact indicator. This only indicator, while straightforward to apply, has important drawbacks (Lonsdale, 1999; Morin, 2001, 2008, 2014; Van Loocke and Put, 2010, 2011):

- It only reveals tangible instrumental impact, neglecting the other types of impact;

- It does not take into account the relative importance (in financial or societal terms) of the recommendations and the complexity of implementing them;

- Some improvements are already implemented during the process of auditing itself. In this case, performance auditors will not formulate any recommendations, although there has been impact; 
- Implementing recommendations does not necessarily lead to improvements; and not implementing recommendations is not always a bad thing;

Given these shortcomings, we proceed with an alternative, albeit more encompassing, measurement instrument, which was previously tested in the case of performance audits in Canada (Morin, 2001, 2008, 2014). Before elaborating on the particularities of our survey, we first expand on the characteristics of the Belgian Court.

\section{Our case: the impact of Court of Audit on Belgian federal Administration}

Like many other SAIs in western countries, Belgian Court of Audit promotes the double mission of 'advisor' and 'watchdog'. As mentioned in its annual report (2010, i.e. the period to which this empirical study refers): "The Court aims at improving the functioning of public service through auditing public administrative authorities and assessing the implementation of government policy and the results obtained". The Court has the duty to assist the parliamentary assemblies and the provincial councils in their supervisory function of collecting and spending public funds. It reports on its findings and provides its opinions and recommendations following their government budget reviews and their audit activities (legality, regularity, financial and performance audits). In addition, the Court of Audit is entrusted with a jurisdictional assignment towards the public accounting officers whose accounts are in deficit. The Belgian Court of Audit is, given the federal setting of Belgian, entitled to conduct independent audits of the revenue and expenditure of the entire state: being the Federal State, the Communities and Regions, the subsidiary public bodies thereof and the provinces. Again given the bipolar federal nature of the country, the Court consists of two chambers, one French-speaking and another Dutch-speaking, which jointly constitute the general assembly. Each chamber comprises a president, four councilors and a secretary general. The Belgian court members are appointed by the House of Representatives for a renewable term of six years. The Belgian Court of Audit is a member of INTOSAI and is hence subjected to its professional standards. To be clear, the scope of the audits investigated in the present study only concerns the Belgian federal government. The Court of Audit's Federal State audit field is split up in seventeen policy domains: justice, social security and public 
health are among the most important (in terms of material weight) domains (Belgian Court of Audit, 2010).

\section{Measuring the impact of the Belgian Court of Audit through its performance audits}

We have measured the impact of the Court from ten angles, and thus expanded the scant knowledge in the literature of the true impact that SAIs exert on management of Administrations through performance audits. The ten elements of measurement that underpin the model used to evaluate the impact of performance audits on the management of the Belgian federal Administration are mainly derived from the works of Pollitt et al. (1999) and Morin (2000, 2001, 2008, 2014). The set of variables allows us to measure the three types of impact that we earlier referred to. Where applicable, we mention in parentheses the type of use. The variables measured are the same presented in Morin $(2008,2014)$ :

(1) contribution of performance audits (Instrumental/Conceptual);

(2) relevance of auditors' recommendations;

(3) preventive effect exerted by performance audits on auditees (cfr. Lonsdale, 1999);

(4) influence exerted by the performance audit on auditees' management practices (Instrumental);

(5) influence exerted by the performance audit on the audited organization's relations with stakeholders (Instrumental);

(6) usefulness of auditors' reports (Instrumental/Conceptual/Strategic);

(7) concrete actions taken by auditees following the performance audit (Instrumental);

(8) organizational consequences of audits;

(9) personal consequences of audits; and

(10) perceived overall impact on the management of the organization audited.

The conditions (also taken from Morin: 2008, 2014) that might have influenced the Court of Audit's ability to exert its influence on Administration through its performance audits have been tested on respondents who completed the survey questionnaire. Respondents 
were asked whether the conditions below, if applicable, helped or hindered the implementation of auditors' recommendations:

- the will of those at the base of the organization,

- the intervention of parliamentarians,

- the departure of key people in the organization audited,

- the place of auditors' recommendations among auditees' priorities,

- the political and central authorities' will,

- the timing of the audit,

- a major reorganization underway in the organization audited or a reform on the government level,

- press coverage.

When linking this to the earlier presented literature review of Van Loocke and Put, we can conclude that the survey does cover all factors of potential causal influence, apart from 'pressure of interest groups' and 'ad hoc events'.

\section{Methodology}

The research was conducted ${ }^{1}$ among the civil servants of the Belgian federal government who were involved in one or more performance audits of the Court of Audit between 2005 and 2010. The audits were compiled from a list of audit reports produced by the Court for its 'Synthesis of norms from performance audits (1998-2011)' (2011). All 49 audit reports published between 2005 and 2010 were considered for the research. The audits involved a varying number of government organizations: between one and 15 per audit. In total, 44 different government organizations were involved. The number of audits per organization during this period (2005-2010) ranged from 1 to 12 .

An oriented sample of respondents was studied. In this approach, it is important that the respondents have "undergone" a performance audit done by the Court, either during the actual audit or during the follow-up of auditors' recommendations, or both.

\footnotetext{
${ }^{1}$ The research was conducted by
} 
Consequently, we needed to enlist the assistance of a top authority within the audited organization, to identify informed respondents. Via email the organizational heads were asked whether they were willing to cooperate, and we asked them to provide a list of email addresses of civil servants involved in the performance audit(s) of their organization. The email invitation did not mention that one of the researchers was employed by the Court. The Belgium Court of Audit was not explicitly asked to take part in this research project.

Our questionnaire was the same as that used in two Canadian studies on the impact of Auditors general on Administrations through performance audits (Morin: 2008, 2014). It was translated into Flemish and administered electronically on the Limesurvey server of KU Leuven University. The first invitation to complete the survey was sent on March 24, 2014, and data collection was finalized by April 20, 2014. The invitation and questionnaire were sent directly to the respondents. The top management of the organization was not informed of the participants' responses, namely whether or not they completed the questionnaire, nor of the nature of the responses to the questionnaire.

Below we provide an overview of the reactions of the 44 Belgian federal organizations following the initial invitation to take part in the survey:

- 26 organizations agreed to participate (although there were six organizations for which we did not receive any completed questionnaire);

- 9 organizations responded they were not willing to cooperate:

- 3 referred to a shortage of staff members and mentioned other priorities,

- 1 organization did not mention any reason;

- 9 organizations did not reply to the invitation.

The survey response rates of the 148 civil servants who were identified by the heads of organizations willing to cooperate are as follows:

\begin{tabular}{|l|c|c|}
\hline & Number & Percentage \\
\hline Response: completed survey & 47 & $32 \%$ \\
\hline Partial non-response: partly completed survey & 30 & $20 \%$ \\
\hline Non-response: no answer & 71 & $48 \%$ \\
\hline
\end{tabular}


The 47 completed surveys (32\% response rate) concern respondents involved in 24 different audits (out of the 49 retrieved). This corresponds to $49 \%$ of all performance audit reports published between 2005 and 2010. The 47 respondents came from 18 different organizations, which represent $41 \%$ of the 44 organizations involved in the performance audits published between 2005 and 2010.

Response rates by type of organizations are distributed as follows:

\begin{tabular}{|c|c|c|}
\hline & $\begin{array}{l}\text { Number of } \\
\text { respondents }\end{array}$ & $\begin{array}{c}\text { Completed questionnaires } \\
(n=47)\end{array}$ \\
\hline Ministry & 33 & $70.2 \%$ \\
\hline Agency & 3 & $6.4 \%$ \\
\hline Governmental organization & 5 & $10.6 \%$ \\
\hline Other & 6 & $12.8 \%$ \\
\hline Totals: & 47 & $100 \%$ \\
\hline
\end{tabular}

Professional categories of respondents are:

\begin{tabular}{|l|c|}
\hline & Completed questionnaires (n=47) \\
\hline Top management & $27.7 \%$ \\
\hline Middle management & $31.9 \%$ \\
\hline Professional & $4.3 \%$ \\
\hline Civil servant level A & $31.9 \%$ \\
\hline Civil servant level B $\quad$ Total: & $4.3 \%$ \\
\hline
\end{tabular}

A 7-point measurement scale was used in this survey. The mean of a sub-variable was calculated by dividing the sum of the values reported by the respondents by the total number of respondents that answered the question assigned to this sub-variable. Let $X$ be a sub-variable whose mean $\bar{X}$ was calculated for a type of organization (Ministry, Agency, Governmental organization, Other) made up of $\mathrm{N}$ respondents. The mean is formulated as: $\bar{X}=\frac{\sum_{i=1}^{n} x_{i}}{n}$, where $x_{i}$ is the value reported by respondent $\mathrm{i}$, included 
between 1 and 7 on a Likert scale; $n \leq N$ is the number of respondents who answered the question referenced by the sub-variable. ${ }^{2}$

The means for all types of organization combined were also calculated as explained above. This calculation corresponds to the sum of the values reported by the respondents, for all types of organization combined, which was divided by the total number of respondents that attributed a value to the sub-variable in question.

Global scores were calculated for the following aggregate variables:

- Contribution of performance audit

- Preventive effect

- Influence on management practices

- Usefulness of auditor's report

- Concrete actions taken following the performance audit

- Consequences for the organization.

These global scores were calculated by computing, for each respondent, the mean of the values of the sub-variables that make up the aggregate variable (for which the global score was calculated). For example, for a given respondent, the sum of the values of the sub-variables constituting the aggregate variable "Preventive effect" for that respondent was divided by the total number of sub-variables for which the respondent reported a value (scale of 1 to 7). A mean for each aggregate variable for all types of organizations was also calculated.

\section{From the auditees' standpoint, what influence did the Court exert on organizational life following the performance audit?}

Auditees surveyed unanimously acknowledged that the Court's reports had a fairly marginal impact on management of organizations audited. The reports promoted some improvement of management (mean of 2.9/7) and did not cause deterioration of 
management (mean of 1.2/7) (see table 1) ${ }^{3}$. In answer to the question "How would you evaluate the impact VFM audit has had on the state of management in your organization?" the auditees surveyed attributed an overall average of 3.2/7, which suggests that auditors had exerted influence on the organizational life of the entities audited, although it was meager.

Global scores calculated (see table 2a) indicate that when the auditees surveyed were asked for their perception of the usefulness of the auditors' report, they were more inclined to recognize added value in the auditors' work in their organization (mean of $4 / 7$ for all types of organizations combined with means of 4.3 for ministries and governmental organizations). The auditors' visit increased auditees' confidence in the operational and control mechanisms in place in their organization, with a mean of 4.2/7 for all types of organizations combined (see table 2b).

We will now examine how each impact variable was evaluated by the auditees surveyed.

\section{Contribution of performance audit (table 3)}

Auditors of the Court were perceived not only as agents of change by the auditees surveyed but also as independent and competent experts that detected or drew attention to important problems in the audited organization (conceptual impact) (see table 3). Auditees thus recognize that auditors had contributed to:

- Highlighting inconsistencies in some of the organization's programs or activities (mean of 4.5/7 for all types of organizations combined); shedding new light on the situation (3.6/7) and having deficiencies noted serve as an example for the organization's other programs (3.1/7);

- Confirming the need for change (mean of 4.4/7 for all types of organizations combined with means of 4.6 for ministries and governmental organizations,

\footnotetext{
${ }^{3}$ When differences between the mean of each type of organization for the variables, sub-variables and global scores were not statistically significant (p-value $>.05)$, the analysis of the respective means of different types of organization is not pertinent and consequently not presented.
} 
differences between the means by type of organization is statistically significant: pvalue <.05); and prompting change (4.2/7);

- Attracting the attention of the deputy minister or the manager concerned (mean of 3.9/7 for all types of organizations combined) and parliamentarians and the public (3.3/7) to a particular problem;

- Obtaining evaluation from an authority external to the organization (mean of 3.9/7 for all types of organizations combined).

To a lesser extent, auditors were perceived as having supported the managers in place. For example, auditees surveyed reported that auditors sometimes supported them in carrying out certain projects (3.6/7) and had helped them improve the quality of information used in decision-making (3.5/7). The respondents also mentioned that auditors sometimes endorsed changes made by managers (3.7/7), corroborated a program evaluation (3.3/7) or allowed the evaluation of programs that the political authorities in office did not want evaluated (3.1/7). Thus, it seems that auditors were occasionally perceived as validating and thereby reinforcing the credibility of auditees' decisions.

Auditors recommendations, namely those related to the implementation of more reliable controls (mean of 3.7/7 for all types of organizations combined, with means of over 4/7 for ministries and governmental organizations) and those related to improvement of existing controls, keeping only those necessary to ensure operational efficiency (3.1/7), were echoed by the auditees surveyed. It seems that auditors are fairly credible to the auditees when they examined controls put in place.

\section{Preventive effect exerted on auditees}

Even if the prevention effect exerted on auditees probably does not measure up to the auditors' expectations, auditors nonetheless made auditees apprehensive, which led them to take measures to prepare for a possible visit by auditors. When asked "In your opinion, how much of a preventive effect is there in knowing that auditors may one day carry out 
a performance audit in your organization?" auditees rated the measures below, which were stated in the questionnaire (see table 4):

- Implementation of preventive and detection controls (mean of $4.1 / 7$, for all types of organizations combined)

- Compliance with the laws and regulations governing the organization (3.9/7)

- Implementation of more efficient management practices (3.8/7)

- Production of more reliable information regarding the organization's performance $(3.7 / 7)$

- Reduction of fraud and dishonesty (3.5/7)

- Waste elimination (3.2/7).

Therefore, regarding the putting in place of adequate controls in organizations, auditors wielded power to influence auditees even when they did not visit that particular organization.

\section{Influence on management practices}

This power that the auditors seem to possess, namely to incite auditees to put appropriate controls in place, was translated very little by the documentation of decisions (mean of $3.6 / 7)$ and by operational and financial controls (3.5/7 with a mean of $4 / 7$ for ministries and governmental organizations). Clearly, auditors are powerless to notably influence auditees' management practices (instrumental impact), in several respects (see table 5).

\section{Usefulness of auditors' reports}

With several means higher than $4 / 7$, this variable seems to have created the widest consensus among the survey respondents. For several sub-variables, these means range from 4 to $4.8 / 7$ for ministries and up to 5.5/7 for governmental organizations (see table 6). Note that these mainly refer to forms of conceptual impact, and to a much lesser 
extent to strategic or instrumental impact. Auditors' reports have thus been useful to auditees, in several ways:

- Stimulate reflection (mean of 4.7/7 for all types of organizations combined; means of 4.8 for ministries and 5.5 for governmental organizations)

- Enrich organizational memory (4.4)

- A valid basis for discussion (mean of 4.4/7 for all types of organizations combined; means of 4.7 for ministries and 4.8 for governmental organizations)

- Move from discussion to action (4.3)

- Validate positions taken or observations made (mean of 4.3/7 for all types of organizations combined; means of 4.7 for ministries and 5 for governmental organizations)

- Learn from mistakes (mean of 4.3/7 for all types of organizations combined; means of 4.6 for ministries and 5 for governmental organizations)

- Provide data useful in implementing certain projects (mean of 4.2/7 for all types of organizations combined; means of 4.6 for ministries and 5 for governmental organizations)

- Clear up a situation (4)

- Serve as a strong point in arguments between different parties (mean of 4/7 for all types of organizations combined; means of 4.2 for ministries and 4.8 for governmental organizations).

\section{Concrete actions taken following performance audits}

Performance audits did not truly drive initiatives such as rationalization of operations (mean of 3.3/7 for all types of organizations combined; means higher than 3.7 in ministries), or reorganization of the organization or information systems, program reform or amendment of existing laws or regulations (means of 3 or lower) (see table 7) (i.e. forms of instrumental impact). Note that these operations are generally ordered by the political powers. Auditors' influence is understandably marginal in this context. 


\section{Consequences for the organization}

The negative consequences that the literature (Carson \& Carson, 1993; Deming, 1986; Leeuw, 1996a), 1996b), 1997; Parker, 1986; Smith, 1993, 1995) anticipates when managers' performance is evaluated were not manifested in this study whether we questioned the respondents about the negative consequences on their organization or on themselves.

Auditees surveyed almost unanimously confirmed that performance audits did not have negative consequences in their organization (see Table 8). The following conditions were tested:

- Increase in the organization's short-term operating costs with no mid-term benefits to compensate for the increase $(1.5 / 7)$

- Multiplication of controls extensive enough to hinder achievement of objectives (1.5)

- Dissatisfaction of target clienteles owing to a considerable loss of efficiency in the delivery of services following implementation of additional controls recommended by the auditors (1.4)

- Organizational paralysis (1.3).

\section{Impact on you personally}

None of the sub-variables exceeded 3/7 regarding the potential effects of a performance audit on the auditees personally (see table 9). The good news is that none of the negative consequences stated in the literature was manifested, specifically a loss of motivation, tendency to restrain auditee's initiatives, negative influence on future work and on career or a decline in performance.

\section{Relevance of the recommendations}

The auditees attributed an average of $4.9 / 7$ for all types of organizations combined to affirm that auditors' recommendations were appropriate, realistic and applicable (see 
table 10). This is good news for auditors, especially because flaws in recommendations formulated are exceptional. Auditees surveyed nonetheless claimed that auditors' recommendations were sometimes theoretically valid but difficult to apply (mean of 3.9/7 for all types of organizations combined). For the other shortcomings tested, the mean was at most 2.9/7 (see table 10 for results obtained for the other sub-variables).

\section{Relations with interest groups}

Auditees were asked whether performance audits had improved or worsened relations with interest groups below (see table 11):

- Citizens who are clients of the organization;

- Partners of the organization (other organizations, firms, etc.);

- Central agencies (Ministry, Treasury Board, Executive Council, etc.);

- Political agencies (Minister, Parliamentarians);

- General public.

Here, the impact of the audit is very marginal: means were at most 2.9/7 (for all types of organizations combined) for improvement of relations, and worsening of relations was at most 1.8/7 (which signals practically no impact noted by the auditees surveyed).

\section{Influence of environmental conditions on the impact of the performance audit}

Auditors' successes and failures when they try to influence the management of organizations audited are not dictated solely by the auditors' own actions. This is why respondents were asked to appreciate conditions that might have favored or weakened auditors' influence. 


\section{Environmental conditions}

Auditees rated several environmental conditions inspired by previous works (Pollitt et al., 1999; Morin, 2001; Van Loocke and Put, 2010, 2011) (see Table 12). Only the place of auditors' recommendations within priorities guiding management in the organization audited (mean of 3.3/7 for all types of organizations combined) and the will of those at the base of the organization audited (3.2/7) seems to have somewhat influenced auditors' impact on the audited organization. The will of central authorities (2.6/7) and political will (2.5/7) played a smaller role. These conditions thus reinforced the impact auditors envisioned. In addition, none of the conditions tested dampened auditors' impact (means of 1.8 and under for all sub-variables).

\section{Parliamentarians' involvement}

Of the 47 respondents who completed the survey, only 13 stated that the performance audit led to a hearing before a parliamentary committee (see Table 14). The responses of these 13 auditees show that the impact of Parliamentarians on the course of actions after the performance audit was marginal. The good news for auditors is that when manifested, the influence of Parliamentarians has a positive effect on the follow-up by auditees (see table 15):

- Acceleration of implementation of concrete measures to correct the problems spotted by auditors (mean of 3.1/7 for all types of organizations combined)

- Acceleration of move from discussion to action concerning the problems spotted by auditors (3.2)

- Creation of a sense of urgency among auditees to make corrections for the problems spotted by auditors (3.1).

Even if the impact of Parliamentarians is not pronounced (perhaps because a limited number of audit reports were discussed before a committee), the results are nonetheless coherent with the impacts anticipated in the literature, namely that Parliamentarians' 
actions contribute to accelerating auditees' application of recommendations (Malloy 2004; Morin, 2008; Pollitt et al. 1999).

\section{Press involvement}

Only eight respondents (out of 47) affirmed that auditors' reports received press coverage (see table 16). Here again, the effect of this coverage reinforces auditors' actions. This influence was felt because it reactivated the debate among political authorities (mean of 3.1/7 for all types of organizations combined) and it forced the correction of serious deficiencies in the organizations' operations (3.3/7) (see table 17). The auditees surveyed did not perceive negative consequences related to this press coverage.

\section{Relations with the auditors}

The fluidity of communications between auditors and auditees (mean of 4.2/7 for all types of organizations combined) and openness shown by auditors (4.1/7) contributed the most to reinforcing the impact sought by auditors (see table 13a). The auditees surveyed recognize that auditors' actions in audited organizations were credible and legitimate (3.9/7). The most frequently seen source of dissatisfaction regarding the presence of auditors at their organization was the increased workload of auditees (mean of 3.5/7) (see table 13b).

\section{Discussion and conclusion}

Having an impact on the Administrations audited is part of the rationale of most of the Supreme Audit Institutions, as we stipulated in the introduction of this article. Systematic evidence on this impact still remains scarcely available. With this study, we have tried to go beyond the "wishful thinking" about the impact of the performance audits of the Court of Audit on Belgian federal Administration. We have also studied the factors that might have influenced this impact. We replicated a survey that has earlier been conducted in a Canadian (Morin, 2008, 2014), i.e. Westminster-style context. As such, the results 
present an independent test and external validity check of the Canadian findings in a Napoleonic court tradition. However, we did not envisage a full-fledged comparative study. In addition, the survey provided the opportunity to test, for the first time, a comprehensive model, developed by Van Loocke and Put $(2010,2011)$ on factors that influence SAIs' impact on Administrations. Consequently, our findings might be relevant for academic and for practitioner purposes as well.

Do SAIs' performance audits have an impact on the Administrations audited? Our study revealed that performance audits that were conducted by the Belgian Court of Audit between 2005 and 2010, did have an - although limited - impact on the audited entities. This finding confirms what Morin $(2008,2014)$ stated in a Canadian context: there were no radical changes or 'palace revolutions' in the organizations under study, but the impact of the intervention of the auditors was noticeable. This impact was not invasive, but 'slow and subtle' (Morin, 2008, p. 717). The nature of the impact was rather conceptual than strategic or instrumental. This supports what is known from the literature on policy evaluation, namely that conceptual impact usually precedes the other two forms (Cummings, 2002; Van Loocke \& Put, 2010). The expectation that audits could have a negative psychological impact, like Lonsdale (1999) suggested, could not be confirmed in the Canadian context (Morin, 2008, 2014), just as little as in this Belgian study.

Which factors contribute to the impact of SAIs' performance audits? Morin's questionnaire allowed examining the relevance of variables identified by Van Loocke and Put (2010) which they judged as plausible causal factors in reinforcing the impact of performance audits. According to the respondents surveyed, all factors, or at least those that could be measured in our research, turned out to have a small to perceptible effect on impact. Of the factors at micro-level (i.e. related to the audit), the relations with the auditor (like fluidity of communications, openness shown by the auditors, recognition of the credibility and legitimacy of the auditors by the auditees) and the qualities attributed to the recommendations (appropriate, realistic and applicable) seemed important. This confirms the importance of collaborative processes with more regard and empathy for the audited organization's context, as was recently concluded by Van Acker et al (2014) on the basis of case studies in six European countries. The importance of the factors at meso- 
level (concerning the Court and the auditees) was recognized mainly through the will of those at the base of the organization, but other factors seemed relevant but to a lesser extent, notably the place of auditor's recommendations within the priorities guiding management, the will of central authorities and political will. Morin (2014) suggested that a consensus between the three centers of power with regard to the recommendations of the auditors - those at the base of the organization, management and politics - is important to their implementation. However, the little number of reports discussed by Parliamentarians and spotted by the press (mentioned by the respondents) prevents us to conclude about the actual influence of this factor in the Belgian federal context.

In this first time study on Belgium Court of Audit's impact on Administration through its performance audits over a five-year period, the auditees surveyed did not question the legitimacy of the Court. Their perception of the auditors' work is rather positive and they pay attention to Court's recommendations considered as appropriate and relevant. One of the options that is considered in this respect, is whether the questionnaire of this study can be replicated on a regular base. This is a merit of this research in itself. And perhaps this can pave the way for future systematic impact studies in other countries as well.

This being said, more and better impact studies remain necessary. Only on the basis of Morin's questionnaire, an extensive research agenda could be developed. Next to internationally comparative research, which can help to get insight in the reinforcing factors at macro-level (e.g. a more in-depth study on the differences between the Westminster and Napoleonic tradition), it would, for instance, be interesting to compare the different levels of government in Belgium, to collect more information on factors at meso-level. Because some relevant institutional aspects differ strongly (e.g. in Flanders almost all performance audit reports are debated in the Flemish Parliament and get extensive media coverage), involving the other state levels in the study could have led to other findings. The differences between government organizations, and between civil servants of different levels, could also be further investigated.

We realize that much bigger and high quality samples are needed, to have a full understanding of the complexity of the relationships between all possible influencing factors. Such samples would also enable to operationalize impact in a more fine-grained 
way, on the basis of factor scores for the different elements. However, these ambitions could be better achieved with the cooperation of the SAIs: when the auditees can be identified via the auditors, the sample could be more targeted, with a higher chance of relevance of the responses to the survey. This strategy would as well allow linking the auditees to specific audits, rather than assessing all performance audits of an organization as a whole.

Further research should also include more objective data on the impact of the audits to complement the methodology we used in this study, which only tests the subjective perception of the impact of one party involved. It must be recognized that performance auditing takes place within an accountability relationship with three parties: a Supreme Audit Institution audits the Administration and Government and reports on these to the Parliament. In addition, the media and interest groups play an important role as mediator of the audit findings. A combination of the present survey, with the percentage of implemented recommendations (i.e. the 'traditional' impact indicator, with its known backdrops), third party interviews, and case studies, would give a more valid image of the real impact of the audits under study. Moreover, a more complex conception of causality, which gives account to set theoretic notions of necessary and sufficiency, and non-linear causality, would enrich possible findings. Such alternative conceptions would require different methods: configurational comparative methods such as Qualitative Comparative Analysis would be a logical avenue.

An unclaimed, but related, topic remains the use of audits by the Parliamentarians. To what extent, and in which way do Parliamentarians use the audits that are conducted? This was studied in a Canadian context when Sheila Fraser was Auditor General from 2001-2011 (Morin, 2015). However, the Parliamentarians' use of SAIs reports remains also a field scarcely visited in western Administrations. This absence of empirical data about the influence of SAIs on Parliamentarians' debates contributes to the perpetuation of the "magical thinking" when it comes to assess the actual influence of SAIs through the performance audits they have been conducting in the Administrations for nearly 40 years. 
Table 1 - Overall impact on organization audited

\begin{tabular}{l|c|c|c|c|c|c|}
\multicolumn{1}{c|}{ Variable } & Ministry & Agency & $\begin{array}{c}\text { Governmental } \\
\text { Organization }\end{array}$ & Other & All & $\begin{array}{c}\text { p- } \\
\text { value* }\end{array}$ \\
\hline $\begin{array}{l}\text { Improvement of } \\
\text { management }\end{array}$ & 3 & 1 & 3.4 & 2.7 & 2.9 & 0.1574 \\
\hline $\begin{array}{l}\text { Deterioration of } \\
\text { management }\end{array}$ & 1.3 & 1 & 1.2 & 1 & 1.2 & .6628 \\
\hline $\begin{array}{l}\text { Overall effect of } \\
\text { performance audit }\end{array}$ & 3.4 & 1.7 & 3.2 & 3.3 & 3.2 & 0.1112 \\
\hline $\begin{array}{l}\text { Notes: } \\
\text { *Significant at the } 0.05 \text { level } \\
\text { Seven-category Likert-type scale }\end{array}$
\end{tabular}

\section{Table 2a - Global scores}

\begin{tabular}{l|c|c|c|c|c|c|}
\multicolumn{1}{c|}{ Variable } & Ministry & Agency & $\begin{array}{c}\text { Governmental } \\
\text { Organization }\end{array}$ & Other & All & $\begin{array}{c}\text { p- } \\
\text { value* }\end{array}$ \\
\hline $\begin{array}{l}\text { Contribution of } \\
\text { performance audit }\end{array}$ & 3,8 & 1,7 & 4,0 & 2,9 & 3,6 & $0.0178^{*}$ \\
\hline Preventive effect & 3,8 & 2,4 & 3,9 & 3,3 & 3,6 & 0,4220 \\
\hline $\begin{array}{l}\text { Influence on } \\
\text { management } \\
\text { practices }\end{array}$ & 3,4 & 1,7 & 3,0 & 2,3 & 3,1 & 0,1426 \\
\hline $\begin{array}{l}\text { Usefulness of } \\
\text { auditors reports }\end{array}$ & 4,3 & 1,7 & 4,3 & 3,2 & 4 & $0.0133^{*}$ \\
\hline $\begin{array}{l}\text { Concrete actions } \\
\text { taken following the } \\
\text { performance audit }\end{array}$ & 2,8 & 1,2 & 2,4 & 2,4 & 2,6 & 0,2161 \\
\hline $\begin{array}{l}\text { Consequences for the } \\
\text { organization }\end{array}$ & 1,5 & 1,0 & 1,5 & 1,1 & 1,4 & 0,3623 \\
\hline
\end{tabular}

Notes:

*Significant at the 0.05 level

Seven-category Likert-type scale

\section{Table 2b - Reliability Seal}

\begin{tabular}{|l|l|c|c|c|c|c|}
\hline $\begin{array}{l}\text { Has the audit influenced your } \\
\text { confidence in the reliability of } \\
\text { your organization's operating } \\
\text { and control mechanisms? }\end{array}$ & Ministry & Agency & $\begin{array}{c}\text { Governmental } \\
\text { organization }\end{array}$ & Other & All & $\begin{array}{c}\text { p- } \\
\text { value* }\end{array}$ \\
\hline It has made me more confident & 4.1 & 1.7 & 5 & 5.2 & 4.2 & $0.0151^{*}$ \\
\hline It has made me less confident & 2.4 & 1 & 2.5 & 1.4 & 2.2 & 0.1823 \\
\hline $\begin{array}{l}\text { Notes: } \\
* \text { Significant at the o.05 level } \\
\text { Seven-category Likert-type scale }\end{array}$
\end{tabular}


Table 3 - Contribution of performance audits

\begin{tabular}{|c|c|c|c|c|c|c|}
\hline Sub-variables & Ministry & Agency & $\begin{array}{l}\text { Governmental } \\
\text { Organization }\end{array}$ & Other & All & $\begin{array}{c}\text { p- } \\
\text { value* }\end{array}$ \\
\hline $\begin{array}{l}\text { Highlighting inconsistencies in some of the } \\
\text { organization's programs or activities }\end{array}$ & 4.6 & 3.3 & 5.2 & 4 & 4.5 & 0.3578 \\
\hline Confirming the need for change & 4.6 & 1.3 & 4.6 & 4.8 & 4.4 & $0.0446^{*}$ \\
\hline Prompting change & 4.6 & 1.7 & 4.2 & 3.8 & 4.2 & 0.0581 \\
\hline $\begin{array}{l}\text { Obtaining evaluation from an authority } \\
\text { external to the organization }\end{array}$ & 4 & 2.7 & 3.8 & 4 & 3.9 & 0.822 \\
\hline $\begin{array}{l}\text { Attracting the attention of the deputy } \\
\text { minister or the manager concerned to a } \\
\text { particular problem }\end{array}$ & 3.9 & 1.3 & 4.8 & 4.4 & 3.9 & 0.1180 \\
\hline Endorsing changes made & 3.8 & 1.3 & 4.8 & 3.2 & 3.7 & 0.0509 \\
\hline Establishing more reliable controls & 4.1 & 1.7 & 4.8 & 2.5 & 3.7 & $0.0102 *$ \\
\hline $\begin{array}{l}\text { Establishing controls guaranteeing the } \\
\text { fairness of decisions made by the } \\
\text { organization? }\end{array}$ & 4 & 1.7 & 4.3 & 2.4 & 3.7 & $0.0483 *$ \\
\hline Shedding new light on the situation & 3.9 & 2 & 3.2 & 3.2 & 3.6 & 0.1699 \\
\hline $\begin{array}{l}\text { Supporting management in carrying out } \\
\text { certain projects }\end{array}$ & 4 & 1.3 & 2.6 & 3.2 & 3.6 & 0.0668 \\
\hline $\begin{array}{l}\text { Improving the quality of information used } \\
\text { in decision-making }\end{array}$ & 3.9 & 1.7 & 3.8 & 2.3 & 3.5 & $0.0430 *$ \\
\hline Corroborating a program evaluation & 3.6 & 1.7 & 3.3 & 2.4 & 3.3 & 0.3514 \\
\hline $\begin{array}{l}\text { Attracting the attention of parliamentarians } \\
\text { and the public to a particular problem }\end{array}$ & 3.6 & 1.3 & 4.5 & 2.2 & 3.3 & 0.1400 \\
\hline $\begin{array}{l}\text { Allowing the evaluation of programs that } \\
\text { the political authorities in office did not } \\
\text { want evaluated }\end{array}$ & 3.4 & 1.3 & 3 & 2.4 & 3.1 & 0.3742 \\
\hline $\begin{array}{l}\text { Serving as an example for the } \\
\text { organization's other programs? }\end{array}$ & 3.2 & 1.3 & 5 & 1.8 & 3.1 & $0.0025^{*}$ \\
\hline $\begin{array}{l}\text { Streamlining existing controls, keeping } \\
\text { only those necessary to ensure operational } \\
\text { efficiency }\end{array}$ & 3.4 & 1.7 & 4 & 1.4 & 3.1 & $0.0406^{*}$ \\
\hline Reducing operating costs & 2.1 & 1.3 & 2.6 & 1.7 & 2 & 0.6229 \\
\hline
\end{tabular}

Notes:

* Significant at the 0.05 level

Seven-category Likert-type scale 
Table 4 - Preventive effect

\begin{tabular}{|c|c|c|c|c|c|c|}
\hline Sub-variables & Ministry & Agency & $\begin{array}{l}\text { Governmental } \\
\text { Organization }\end{array}$ & Other & All & $\begin{array}{c}\text { p- } \\
\text { value* }\end{array}$ \\
\hline $\begin{array}{l}\text { Implementation of preventive and } \\
\text { detection controls }\end{array}$ & 4.2 & 3.3 & 5 & 3.6 & 4.1 & 0.5623 \\
\hline $\begin{array}{l}\text { Compliance with the laws and regulations } \\
\text { governing your organization }\end{array}$ & 3.9 & 3 & 4.8 & 3.6 & 3.9 & 0.5025 \\
\hline $\begin{array}{l}\text { Implementation of more efficient } \\
\text { management practices }\end{array}$ & 3.9 & 1.7 & 4.3 & 3.8 & 3.8 & 0.2124 \\
\hline $\begin{array}{l}\text { Production of more reliable information } \\
\text { regarding the organization's performance }\end{array}$ & 3.8 & 2.7 & 4 & 3.6 & 3.7 & 0.7739 \\
\hline Reducing fraud and dishonesty & 3.6 & 3 & 3.6 & 3.2 & 3.5 & 0.9407 \\
\hline Waste elimination & 3.6 & 1.7 & 2.6 & 2.6 & 3.2 & 0.1833 \\
\hline
\end{tabular}




\section{Table 5 - Influence on management practices}

\begin{tabular}{l|c|c|c|c|c|c|}
\hline Sub-variables & Ministry & Agency & $\begin{array}{c}\text { Governmental } \\
\text { Organization }\end{array}$ & Other & All & $\begin{array}{c}\text { p- } \\
\text { value* }\end{array}$ \\
\hline $\begin{array}{l}\text { Management practices related to } \\
\text { documentation of decisions made }\end{array}$ & 4 & 1.7 & 3.8 & 2.6 & 3.6 & 0.0868 \\
\hline $\begin{array}{l}\text { Management practices related to financial } \\
\text { and operational control }\end{array}$ & 4 & 1.7 & 4 & 1.8 & 3.5 & $0.0316^{*}$ \\
\hline $\begin{array}{l}\text { Management practices related to work } \\
\text { organization }\end{array}$ & 3.6 & 1.7 & 3.6 & 2.8 & 3.4 & 0.2528 \\
\hline $\begin{array}{l}\text { Management practices related to the } \\
\text { definition of priorities }\end{array}$ & 3.3 & 1.7 & 4 & 4 & 3.3 & 0.2749 \\
\hline $\begin{array}{l}\text { Use of strategic planning as a management } \\
\text { tool }\end{array}$ & 3.2 & 1.7 & 2.8 & 2.8 & 3 & 0.5800 \\
\hline $\begin{array}{l}\text { Management practices related to } \\
\text { management information used in decision- } \\
\text { making }\end{array}$ & 3.3 & 1.7 & 2.8 & 2.4 & 3 & 0.4238 \\
\hline $\begin{array}{l}\text { Management practices related to } \\
\text { performance measurement }\end{array}$ & 3.5 & 1.7 & 2.5 & 1.2 & 3 & $0.0274^{*}$ \\
\hline $\begin{array}{l}\text { Management practices related to } \\
\text { performance checks with regard to } \\
\text { previous performance commitments }\end{array}$ & 3.4 & 1.7 & 3 & 1.4 & 3 & 0.0939 \\
\hline $\begin{array}{l}\text { Use of annual operational plans as a } \\
\text { management tool }\end{array}$ & 3.1 & 1.7 & 2.8 & 2.6 & 2.9 & 0.5848 \\
\hline $\begin{array}{l}\text { Management practices related to better } \\
\text { program outcomes }\end{array}$ & 3.4 & 1.7 & 2.5 & 1.8 & 2.9 & 0.1776 \\
\hline $\begin{array}{l}\text { Intensified efforts in personnel training } \\
\text { Intensified efforts to communicate to } \\
\text { personnel information about orientations } \\
\text { and mission }\end{array}$ & 3 & 1.7 & 2.6 & 2.6 & 2.8 & 0.6218 \\
\hline $\begin{array}{l}\text { Management practices related to increased } \\
\text { productivity }\end{array}$ & 3.1 & 1.7 & 2.5 & 1.2 & 2.7 & 0.1295 \\
\hline $\begin{array}{l}\text { Notes: Significant at the 0.05 level } \\
\text { Seven-category Likert-type scale }\end{array}$ & 3 & 2.6 & 2.6 & 2.8 & 0.5789 \\
\hline
\end{tabular}


Table 6 - Usefulness of auditors' reports

\begin{tabular}{|c|c|c|c|c|c|c|}
\hline Sub-variables & Ministry & Agency & $\begin{array}{c}\text { Governmental } \\
\text { Organization }\end{array}$ & Other & All & $\begin{array}{c}\text { p- } \\
\text { value* }\end{array}$ \\
\hline Stimulate reflection & 4.8 & 2 & 5.5 & 4.8 & 4.7 & $0.0400 *$ \\
\hline Enrich organizational memory & 4.6 & 2 & 5.3 & 3.6 & 4.4 & 0.0778 \\
\hline A valid basis for discussion & 4.7 & 1.3 & 4.8 & 4.2 & 4.4 & $0.0424 *$ \\
\hline Move from discussion to action & 4.6 & 2.7 & 4 & 3.6 & 4.3 & 0.3393 \\
\hline $\begin{array}{l}\text { Validate positions taken or observations } \\
\text { made }\end{array}$ & 4.7 & 2 & 5 & 3 & 4.3 & $0.0165^{*}$ \\
\hline Learn from mistakes & 4.6 & 2 & 5 & 3.2 & 4.3 & $0.0350^{*}$ \\
\hline $\begin{array}{l}\text { Provide data useful in implementing } \\
\text { certain projects }\end{array}$ & 4.6 & 1.7 & 5 & 2.8 & 4.2 & $0.0224^{*}$ \\
\hline Clear up a situation & 4.3 & 2 & 3.5 & 3.2 & 4 & 0.1873 \\
\hline $\begin{array}{l}\text { Strong point in arguments between } \\
\text { different parties }\end{array}$ & 4.2 & 1 & 4.8 & 4.4 & 4 & $0.0391^{*}$ \\
\hline $\begin{array}{l}\text { Evaluate management practices more } \\
\text { objectively }\end{array}$ & 4.3 & 1.7 & 4.3 & 2 & 3.8 & $0.0095^{*}$ \\
\hline Reinforce sound management principles & 4.1 & 2 & 4.7 & 2 & 3.8 & $0.0292^{*}$ \\
\hline $\begin{array}{l}\text { An opportunity to challenge teams and } \\
\text { programs }\end{array}$ & 4.2 & 1.3 & 4 & 3.2 & 3.8 & 0.0779 \\
\hline Realign programs. Services & 4.3 & 1.3 & 3.8 & 2 & 3.7 & $0.0254^{*}$ \\
\hline $\begin{array}{l}\text { An opportunity to pressure central } \\
\text { authorities or other parties }\end{array}$ & 4.1 & 1 & 2.8 & 4 & 3.7 & 0.1006 \\
\hline Realign policies & 3.9 & 2 & 2.8 & 2.2 & 3.5 & 0.1160 \\
\hline $\begin{array}{l}\text { A weapon for the opposition or interest } \\
\text { groups }\end{array}$ & 3.8 & 2 & 4 & 2.8 & 3.5 & 0.4154 \\
\hline $\begin{array}{l}\text { Facilitate the signing of agreements or } \\
\text { protocols }\end{array}$ & 3.3 & 1 & 2.7 & 2.8 & 3 & 0.3734 \\
\hline
\end{tabular}

Notes:

* Significant at the 0.05 level

Seven-category Likert-type scale 
Table 7 - Concrete actions taken following performance audits

\begin{tabular}{|c|c|c|c|c|c|c|}
\hline Sub-variables & Ministry & Agency & $\begin{array}{c}\text { Governmental } \\
\text { Organization }\end{array}$ & Other & All & $\begin{array}{c}\text { p- } \\
\text { value* }\end{array}$ \\
\hline Rationalization of operations & 3.7 & 1.7 & 3 & 1.8 & 3.3 & $0.0447^{*}$ \\
\hline Reorganization of the organization & 3.1 & 1.7 & 3 & 2.6 & 3 & 0.6404 \\
\hline Program reform & 3.4 & 1.7 & 2.8 & 2.2 & 3 & 0.2787 \\
\hline Reorganization of information systems & 3.3 & 1 & 2.8 & 2.2 & 2.9 & 0.2421 \\
\hline Amendment of existing laws or regulations & 3.2 & 1 & 2.4 & 3.2 & 2.9 & 0.2961 \\
\hline Adoption of new laws or regulations & 3 & 1 & 2 & 3.2 & 2.7 & 0.3008 \\
\hline $\begin{array}{l}\text { Creation of new work groups or reform of } \\
\text { existing groups }\end{array}$ & 2.8 & 1 & 2 & 3.2 & 2.6 & 0.3975 \\
\hline Recruitment of additional staff & 1.9 & 1 & 1.6 & 2.2 & 1.8 & 0.7264 \\
\hline Layoff of existing staff & 1.2 & 1 & 1.6 & 1 & 1.2 & 0.5669 \\
\hline
\end{tabular}


Table 8 - Consequences for the organization

\begin{tabular}{l|c|c|c|c|c|c|}
\hline Sub-variables & Ministry & Agency & $\begin{array}{c}\text { Governmental } \\
\text { Organization }\end{array}$ & Other & All & $\begin{array}{c}\text { p- } \\
\text { value* }\end{array}$ \\
\hline $\begin{array}{l}\text { Increase in the organization's short-term } \\
\text { operating costs with no mid-term benefits } \\
\text { to compensate for the increase }\end{array}$ & 1.5 & 1 & 1.8 & 1.3 & 1.5 & 0.5656 \\
\hline $\begin{array}{l}\text { Multiplication of controls extensive } \\
\text { enough to hinder achievement of } \\
\text { objectives }\end{array}$ & 1.7 & 1 & 1.4 & 1 & 1.5 & 0.3899 \\
\hline $\begin{array}{l}\text { Dissatisfaction of target clienteles owing to } \\
\text { a considerable loss of efficiency in the } \\
\text { delivery of services following } \\
\text { implementation of additional controls } \\
\text { recommended by the auditors }\end{array}$ & 1.5 & 1 & 1.4 & 1 & 1.4 & 0.4158 \\
\hline \begin{tabular}{l} 
Organizational paralysis \\
\hline
\end{tabular} & 1.4 & 1 & 1.4 & 1 & 1.3 & 0.5077 \\
\hline
\end{tabular}

Notes:

* Significant at the 0.05 level

Seven-category Likert-type scale 
Table 9 - Impact on you personally

\begin{tabular}{|c|c|c|c|c|c|c|}
\hline Sub-variables & Ministry & Agency & $\begin{array}{l}\text { Governmental } \\
\text { Organization }\end{array}$ & Other & All & $\begin{array}{c}\text { p- } \\
\text { value* }\end{array}$ \\
\hline $\begin{array}{l}\text { Tendency to encourage you to take certain } \\
\text { initiatives }\end{array}$ & 3 & 1.3 & 2.6 & 3 & 2.9 & 0.4394 \\
\hline Increase in motivation & 3.1 & 1.7 & 2.6 & 2.2 & 2.8 & 0.4097 \\
\hline Improvement in your performance & 2.7 & 1.3 & 2.2 & 1.8 & 2.4 & 0.3405 \\
\hline $\begin{array}{l}\text { Tendency to promote mid- to long-term } \\
\text { objectives }\end{array}$ & 2.5 & 1.7 & 2.2 & 2 & 2.4 & 0.7321 \\
\hline Your superiors have become less confident & 2 & 1 & 2 & 1.5 & 1.9 & 0.5698 \\
\hline $\begin{array}{l}\text { Positive influence on your future work or } \\
\text { on your career }\end{array}$ & 2.1 & 1 & 2.4 & 1.2 & 1.9 & 0.2691 \\
\hline $\begin{array}{l}\text { Your superiors have become more } \\
\text { confident }\end{array}$ & 1.8 & 1.3 & 1.8 & 1.3 & 1.7 & 0.8007 \\
\hline $\begin{array}{l}\text { Your subordinates have become less } \\
\text { confident }\end{array}$ & 1.8 & 1.7 & 1.4 & 2 & 1.7 & 0.8844 \\
\hline $\begin{array}{l}\text { Your subordinates have become more } \\
\text { confident }\end{array}$ & 1.8 & 1 & 2 & 1 & 1.6 & 0.2124 \\
\hline $\begin{array}{l}\text { Tendency to focus on the attainment of } \\
\text { short-term objectives at the expense of } \\
\text { long-term ones }\end{array}$ & 1.8 & 1 & 1.4 & 1 & 1.5 & 0.3503 \\
\hline Loss of motivation & 1.4 & 1 & 1.4 & 1 & 1.3 & 0.5944 \\
\hline Tendency to restrain your initiatives & 1.4 & 1 & 1.6 & 1 & 1.3 & 0.4653 \\
\hline $\begin{array}{l}\text { Negative influence on your future work or } \\
\text { on your career }\end{array}$ & 1.4 & 1 & 1.6 & 1 & 1.3 & 0.6937 \\
\hline Decline in your performance & 1.1 & 1 & 1.4 & 1 & 1.1 & 0.4641 \\
\hline
\end{tabular}

Notes:

* Significant at the 0.05 level

Seven-category Likert-type scale 
Table 10 - Relevance of recommendations

\begin{tabular}{l|c|c|c|c|c|c|}
\hline Sub-variables & Ministry & Agency & $\begin{array}{c}\text { Governmental } \\
\text { Organization }\end{array}$ & Other & All & $\begin{array}{c}\text { p- } \\
\text { value* }\end{array}$ \\
\hline $\begin{array}{l}\text { Recommendations are appropriate, } \\
\text { realistic and applicable }\end{array}$ & 5.1 & 3.3 & 4.8 & 5.2 & 4.9 & 0.2226 \\
\hline $\begin{array}{l}\text { Recommendations theoretically valid but } \\
\text { difficult to apply }\end{array}$ & 3.9 & 4 & 4.5 & 3.2 & 3.9 & 0.6924 \\
\hline $\begin{array}{l}\text { Recommendations do not truly reach the } \\
\text { source of the problem }\end{array}$ & 3.1 & 2 & 2.8 & 2.2 & 2.9 & 0.6031 \\
\hline $\begin{array}{l}\text { Recommendations are outdated because of } \\
\text { important changes in the internal or } \\
\text { external environment of the organization } \\
\text { audited (new management model. } \\
\text { administrative decisions or policies. etc.) }\end{array}$ & 2.8 & 3 & 3.8 & 2.8 & 2.9 & 0.8089 \\
\hline $\begin{array}{l}\text { Recommendations are incompatible with } \\
\text { trends toward management by results. }\end{array}$ & 2.9 & 2 & 4.7 & 2.3 & 2.9 & 0.3359 \\
\hline $\begin{array}{l}\text { Recommendations are incompatible with } \\
\text { trends toward decentralization of decision- } \\
\text { making power }\end{array}$ & 2.8 & 2 & 3.3 & 3 & 2.8 & 0.8553 \\
\hline $\begin{array}{l}\text { Recommendations are incompatible with } \\
\text { trends advocating innovation in public } \\
\text { affairs management }\end{array}$ & 2.9 & 2 & 4.3 & 2 & 2.8 & 0.4354 \\
\hline $\begin{array}{l}\text { Recommendations do not address serious } \\
\text { problems. }\end{array}$ & 2.7 & 3.3 & 3.8 & 1.6 & 2.7 & 0.2663 \\
\hline $\begin{array}{l}\text { Recommendations are incompatible with } \\
\text { trends toward greater empowerment of } \\
\text { public managers. }\end{array}$ & 2.8 & 2.7 & 2.5 & 2 & 2.7 & 0.8763 \\
\hline $\begin{array}{l}\text { Recommendations are too detailed and } \\
\text { narrow, not leaving enough maneuvering } \\
\text { room }\end{array}$ & 2.7 & 2.7 & 3.3 & 1.2 & 2.6 & 0.2188 \\
\hline \begin{tabular}{l} 
Recommendations are too vague \\
\hline
\end{tabular} & 2.5 & 2.3 & 2.3 & 2.2 & 2.4 & 0.9709 \\
\hline
\end{tabular}

Notes:

* Significant at the 0.05 level Seven-category Likert-type scale 
Table 11 - Relations with interests' groups

\begin{tabular}{|l|c|c|c|c|c|c|}
\hline Sub-variables & Ministry & Agency & $\begin{array}{c}\text { Governmental } \\
\text { Organization }\end{array}$ & Other & All & $\begin{array}{c}\text { p- } \\
\text { value* }\end{array}$ \\
\hline $\begin{array}{l}\text { Citizens who are clients of your } \\
\text { organization: improvement in relations }\end{array}$ & 2.7 & 1 & 2.4 & 1 & 2.3 & 0.1143 \\
\hline $\begin{array}{l}\text { Citizens who are clients of your } \\
\text { organization: deterioration in relations }\end{array}$ & 1.9 & 1 & 2 & 1 & 1.7 & 0.4733 \\
\hline $\begin{array}{l}\text { Partners of your organization (other } \\
\text { organizations, firms, etc.): improvement } \\
\text { in relations }\end{array}$ & 3 & 1.7 & 2.4 & 2.4 & 2.8 & 0.5615 \\
\hline $\begin{array}{l}\text { Partners of your organization (other } \\
\text { organizations, firms, etc.): deterioration } \\
\text { in relations }\end{array}$ & 1.7 & 1.7 & 2 & 1.4 & 1.7 & 0.9035 \\
\hline $\begin{array}{l}\text { Central agencies (Ministry, Treasury } \\
\text { Board, Executive Council, etc.): } \\
\text { improvement in relations }\end{array}$ & 3 & 1 & 2.4 & 2.4 & 2.7 & 0.2206 \\
\hline $\begin{array}{l}\text { Central agencies (Ministry, Treasury } \\
\text { Board, Executive Council, etc.): } \\
\text { deterioration in relations }\end{array}$ & 1.7 & 1 & 1.6 & 1.4 & 1.6 & 0.7596 \\
\hline $\begin{array}{l}\text { Political agencies (Minister, } \\
\text { parliamentarians): improvement in } \\
\text { relations }\end{array}$ & 2.4 & 1.3 & 2.8 & 2.2 & 2.4 & 0.4092 \\
\hline $\begin{array}{l}\text { Political agencies (Minister, } \\
\text { parliamentarians): deterioration in } \\
\text { relations }\end{array}$ & 1.8 & 1.3 & 1.6 & 1 & 1.6 & 0.4344 \\
\hline $\begin{array}{l}\text { General public: confirmation of your } \\
\text { organization's credibility }\end{array}$ & 3.2 & 1.3 & 3 & 2 & 2.9 & 0.2300 \\
\hline $\begin{array}{l}\text { General public: deterioration of your } \\
\text { organization's credibility }\end{array}$ & 2 & 2 & 1.4 & 1 & 1.8 & 0.5092 \\
\hline
\end{tabular}

Notes:

* Significant at the 0.05 level

Seven-category Likert-type scale 
Table 12 - Environmental conditions

\begin{tabular}{|c|c|c|c|c|c|c|}
\hline Sub-variables & Ministry & Agency & $\begin{array}{l}\text { Governmental } \\
\text { Organization }\end{array}$ & Other & All & $\begin{array}{c}\text { p- } \\
\text { value* }\end{array}$ \\
\hline $\begin{array}{l}\text { Place of auditors' recommendations within } \\
\text { priorities guiding management in the } \\
\text { organization audited: strengthened impact }\end{array}$ & 3.8 & 2 & 2.5 & 2.4 & 3.3 & 0.1425 \\
\hline $\begin{array}{l}\text { Place of auditors' recommendations within } \\
\text { priorities guiding management in the } \\
\text { organization audited: weakened impact }\end{array}$ & 1.8 & 1.3 & 1.5 & 1 & 1.6 & 0.3199 \\
\hline $\begin{array}{l}\text { Will of those at the base of the } \\
\text { organization audited: strengthened impact }\end{array}$ & 3.7 & 1.7 & 2.3 & 2.2 & 3.2 & $0.0353 *$ \\
\hline $\begin{array}{l}\text { Will of those at the base of the } \\
\text { organization audited: weakened impact }\end{array}$ & 1.7 & 1.3 & 1.5 & 1 & 1.6 & 0.3434 \\
\hline Political will: strengthened impact & 2.6 & 1 & 2.8 & 2.6 & 2.5 & 0.5563 \\
\hline Political will: weakened impact & 1.8 & 1 & 1.5 & 1 & 1.6 & 0.5707 \\
\hline $\begin{array}{l}\text { Will of central authorities: strengthened } \\
\text { impact }\end{array}$ & 2.8 & 1 & 3 & 2.6 & 2.6 & 0.2907 \\
\hline $\begin{array}{l}\text { Will of central authorities: weakened } \\
\text { impact }\end{array}$ & 1.9 & 1 & 1.7 & 1 & 1.6 & 0.2430 \\
\hline $\begin{array}{l}\text { Timing of VFM audit: strengthened } \\
\text { impact }\end{array}$ & 2.1 & 2 & 2.3 & 1 & 2 & 0.3209 \\
\hline Timing of VFM audit: weakened impact & 1.9 & 2 & 1.7 & 1 & 1.8 & 0.4572 \\
\hline $\begin{array}{l}\text { Major reorganization in the organization } \\
\text { audited: strengthened impact }\end{array}$ & 2.2 & 2 & 2.2 & 1.4 & 2.1 & 0.7795 \\
\hline $\begin{array}{l}\text { Major reorganization in the organization } \\
\text { audited: weakened impact }\end{array}$ & 1.6 & 2 & 1.4 & 1 & 1.5 & 0.4092 \\
\hline $\begin{array}{l}\text { Departure of key people: strengthened } \\
\text { impact }\end{array}$ & 1.6 & 1.3 & 1.4 & 1 & 1.5 & 0.4960 \\
\hline $\begin{array}{l}\text { Departure of key people: weakened } \\
\text { impact }\end{array}$ & 1.8 & 1.3 & 1.4 & 1 & 1.6 & 0.3781 \\
\hline $\begin{array}{l}\text { Reform at government level: strengthened } \\
\text { impact }\end{array}$ & 2.4 & 1 & 1.6 & 1.6 & 2.1 & 0.1980 \\
\hline $\begin{array}{l}\text { Reform at government level: weakened } \\
\text { impact }\end{array}$ & 1.7 & 1 & 1.4 & 1 & 1.5 & 0.4300 \\
\hline
\end{tabular}

Notes:

* Significant at the 0.05 level

Seven-category Likert-type scale 
Table 13a - Relations with the auditors

\begin{tabular}{|l|c|c|c|c|c|c|}
\hline Sub-variables & Ministry & Agency & $\begin{array}{c}\text { Governmental } \\
\text { Organization }\end{array}$ & Other & All & $\begin{array}{c}\text { p- } \\
\text { value* }\end{array}$ \\
\hline $\begin{array}{l}\text { Recognition of the credibility of the } \\
\text { auditors: strengthened impact }\end{array}$ & 4 & 3.3 & 4 & 3.6 & 3.9 & 0.9015 \\
\hline $\begin{array}{l}\text { Absence. in your view. of the credibility of } \\
\text { the auditors: weakened impact }\end{array}$ & 1.6 & 1 & 1.6 & 1 & 1.5 & 0.6542 \\
\hline $\begin{array}{l}\text { Recognition of the legitimacy of the } \\
\text { intervention of the auditors: strengthened } \\
\text { impact }\end{array}$ & 3.9 & 3.3 & 4.4 & 3.6 & 3.9 & 0.8534 \\
\hline $\begin{array}{l}\text { Negation of the legitimacy of the } \\
\text { intervention of the auditors: weakened } \\
\text { impact }\end{array}$ & 1.4 & 1 & 2.2 & 1 & 1.4 & 0.2214 \\
\hline $\begin{array}{l}\text { Collegial leadership style shown by the } \\
\text { auditors: strengthened impact }\end{array}$ & 3.1 & 4.7 & 4 & 3.3 & 3.4 & 0.4482 \\
\hline $\begin{array}{l}\text { Authoritarian leadership style shown by } \\
\text { the auditors: weakened impact }\end{array}$ & 1.7 & 1 & 2.3 & 1.8 & 1.7 & 0.6143 \\
\hline $\begin{array}{l}\text { Fluidity of communications between } \\
\text { auditors and auditees: strengthened } \\
\text { impact }\end{array}$ & 4 & 4.7 & 4.8 & 4 & 4.2 & 0.8239 \\
\hline $\begin{array}{l}\text { Problems with communications between } \\
\text { auditors and auditees: weakened impact }\end{array}$ & 1.9 & 1 & 3 & 2 & 2 & 0.4229 \\
\hline $\begin{array}{l}\text { Openness shown by auditors: } \\
\text { strengthened impact }\end{array}$ & 4.2 & 2 & 5 & 3.6 & 4.1 & 0.1605 \\
\hline $\begin{array}{l}\text { Lack of openness shown by auditors: } \\
\text { weakened impact }\end{array}$ & 1.9 & 2.3 & 3.2 & 1.4 & 2.1 & 0.3270 \\
\hline $\begin{array}{l}\text { Notes: } \\
\text { * Significant at the 0.05 level } \\
\text { Seven-category Likert-type scale }\end{array}$ & & & & &
\end{tabular}


Table 13b - Sources of dissatisfaction with auditors

\begin{tabular}{l|c|c|c|c|c|c|}
\hline Sub-variables & Ministry & Agency & $\begin{array}{c}\text { Governmental } \\
\text { Organization }\end{array}$ & Other & All & $\begin{array}{c}\text { p- } \\
\text { value* }\end{array}$ \\
\hline $\begin{array}{l}\text { Auditors' presence adding to your regular } \\
\text { workload }\end{array}$ & 3.4 & 4 & 4.2 & 2.8 & 3.5 & 0.4304 \\
\hline $\begin{array}{l}\text { Auditors' tendency to spend more time on } \\
\text { details than on essentials }\end{array}$ & 3.1 & 1.3 & 2.2 & 2.3 & 2.8 & 0.1818 \\
\hline $\begin{array}{l}\text { Auditors' lack of subtlety and sensitivity to } \\
\text { context. intransigence }\end{array}$ & 2.4 & 1 & 3 & 2.8 & 2.4 & 0.2977 \\
\hline $\begin{array}{l}\text { Report mentioning negative aspects only. } \\
\text { positive aspects mentioned rarely or not at } \\
\text { all }\end{array}$ & 2.2 & 3.3 & 3.5 & 1.5 & 2.4 & 0.2228 \\
\hline Auditors' recommendations not realistic & 2.1 & 1.7 & 3.2 & 2.5 & 2.3 & 0.1821 \\
\hline $\begin{array}{l}\text { Auditors' tendency to favor a } \\
\text { confrontational rather than a collaborative } \\
\text { attitude towards auditees }\end{array}$ & 2.2 & 1 & 2.2 & 2 & 2.1 & 0.5173 \\
\hline $\begin{array}{l}\text { Auditing team's expertise and } \\
\text { understanding of domain audited deemed } \\
\text { inadequate }\end{array}$ & 1.9 & 2.3 & 1.8 & 2 & 1.9 & 0.9611 \\
\hline Auditors' conceptual vision weak & 1.7 & 1.3 & 1.8 & 2.3 & 1.8 & 0.8526 \\
\hline Auditors' evaluations not objective & 1.6 & 1 & 2.5 & 2.2 & 1.7 & 0.2462 \\
\hline Auditors sought sensationalism & 1.2 & 1 & 2.4 & 1 & 1.3 & 0.1147 \\
\hline Auditors' actions and words inconsistent & 1.2 & 1 & 1.8 & 1 & 1.2 & 0.3016 \\
\hline
\end{tabular}

Notes:

* Significant at the 0.05 level

Seven-category Likert-type scale 
Table 14 - Parliamentarians' involvement

\begin{tabular}{|c|c|c|c|c|c|}
\hline $\begin{array}{l}\text { Hearings before a } \\
\text { parliamentary } \\
\text { committee? }\end{array}$ & Ministry & Agency & $\begin{array}{c}\text { Governmental } \\
\text { organization }\end{array}$ & Other & Total \\
\hline No & 24 & 3 & 4 & 3 & 34 \\
\hline Yes & 9 & 0 & 1 & 3 & 13 \\
\hline Total & 33 & 3 & 5 & 6 & 47 \\
\hline
\end{tabular}

\section{Table 15 - Impact of Parliamentarians' involvement}

\begin{tabular}{|l|c|c|c|c|c|c|}
\hline Sub-variables & Ministry & Agency & $\begin{array}{c}\text { Governmental } \\
\text { Organization }\end{array}$ & Other & All & $\begin{array}{c}\text { p- } \\
\text { value* }\end{array}$ \\
\hline $\begin{array}{l}\text { Creation of positive tensions between the } \\
\text { political and administrative arms. }\end{array}$ & 2.8 & - & 4 & 1 & 2.4 & $0.0451^{*}$ \\
$\begin{array}{l}\text { accelerating follow-up on } \\
\text { recommendations }\end{array}$ & 2.5 & - & 4 & 1 & 2.3 & 0.2114 \\
\hline $\begin{array}{l}\text { Creation of negative tensions between the } \\
\text { political and administrative arms. } \\
\text { hindering follow-up on recommendations }\end{array}$ & 3.7 & - & 4 & 1 & 3.1 & 0.1197 \\
\hline $\begin{array}{l}\text { Acceleration of implementation of } \\
\text { concrete measures to correct the problems } \\
\text { spotted by auditors }\end{array}$ & & & & & & \\
\hline $\begin{array}{l}\text { Hampering of implementation of concrete } \\
\text { measures to correct the problems spotted } \\
\text { by auditors }\end{array}$ & 1.7 & - & 4 & 1 & 1.7 & $0.0466^{*}$ \\
\hline $\begin{array}{l}\text { Acceleration of move from discussion to } \\
\text { action concerning the problems spotted by } \\
\text { auditors }\end{array}$ & 3.7 & - & 5 & 1 & 3.2 & 0.0802 \\
\hline $\begin{array}{l}\text { Slowing move from discussion to action } \\
\text { concerning the problems spotted by } \\
\text { auditors }\end{array}$ & 1.7 & - & 3 & 1 & 1.6 & 0.1965 \\
\hline $\begin{array}{l}\text { Creation of a sense of urgency among } \\
\text { auditees to make corrections for the } \\
\text { problems spotted by auditors }\end{array}$ & 3.6 & - & 5 & 1 & 3.1 & 0.1131 \\
\hline $\begin{array}{l}\text { Creation of paralysis among auditees. } \\
\text { rendering them incapable of correcting the } \\
\text { problems spotted by auditors }\end{array}$ & 1.4 & - & 3 & 1 & 1.5 & 0.0679 \\
\hline
\end{tabular}

Notes:

* Significant at the 0.05 level

Seven-category Likert-type scale 
Table 16 - Press' involvement

\begin{tabular}{|c|c|c|c|c|c|}
\hline $\begin{array}{l}\text { Performance } \\
\text { audit report much } \\
\text { covered by the } \\
\text { press? }\end{array}$ & Ministry & Agency & $\begin{array}{l}\text { Governmental } \\
\text { organization }\end{array}$ & Other & Total \\
\hline No & 26 & 2 & 5 & 6 & 39 \\
\hline Yes & 7 & 1 & 0 & 0 & 8 \\
\hline Total & 33 & 3 & 5 & 6 & 47 \\
\hline
\end{tabular}

\section{Table 17 - Impact of press' involvement}

\begin{tabular}{|l|c|c|c|c|c|c|}
\hline Sub-variables & Ministry & Agency & $\begin{array}{c}\text { Governmental } \\
\text { Organization }\end{array}$ & Other & All & $\begin{array}{c}\text { p- } \\
\text { value* }\end{array}$ \\
\hline $\begin{array}{l}\text { Positive effect: it reactivated the debate } \\
\text { among political authorities }\end{array}$ & 3.5 & 1 & - & - & 3.1 & 0.2457 \\
\hline $\begin{array}{l}\text { Negative effect: it reactivated the debate } \\
\text { among political authorities }\end{array}$ & 2 & 1 & - & - & 1.9 & 0.3481 \\
\hline $\begin{array}{l}\text { Positive effect: it forced the correction of } \\
\text { serious deficiencies in the organization's } \\
\text { operations }\end{array}$ & 3.7 & 1 & - & - & 3.3 & 0.3393 \\
\hline $\begin{array}{l}\text { Negative effect: it caused chaos in the } \\
\text { organization's operations }\end{array}$ & 1.7 & 1 & - & - & 1.6 & 0.4838 \\
\hline $\begin{array}{l}\text { Positive effect since it provoked the } \\
\text { departure of incompetent and unproductive } \\
\text { managers }\end{array}$ & 2.2 & 1 & - & - & 2 & 0.6193 \\
\hline $\begin{array}{l}\text { Negative effect: it provoked the departure } \\
\text { of competent and productive managers }\end{array}$ & 1.3 & 1 & - & - & 1.3 & 0.5761 \\
\hline $\begin{array}{l}\text { Positive effect: the auditees tended to be } \\
\text { more prudent in their management } \\
\text { practices in light of the facts reported in } \\
\text { the media }\end{array}$ & 3.2 & 1 & - & - & 2.9 & 0.3910 \\
\hline $\begin{array}{l}\text { Negative effect: the auditees tended to be } \\
\text { overly prudent in their management } \\
\text { practices in light of the facts reported in } \\
\text { the media }\end{array}$ & 1.7 & 1 & - & - & 1.6 & 0.4838 \\
\hline
\end{tabular}




\section{References}

Carson, P.P., Carson, K. D. (1993). Deming versus Traditional Management Theorists on Goal Setting: Can Both Be Right?. Business Horizons 36(5), pp. 79-86.

Cummings, R. (2002). Rethinking evaluation use. Paper presented at the 2002 Australasian Evaluation Society International Conference October/November 2002 - Wollongong Australia

Deming, W. E. (1986). Out of the Crisis. Cambridge, Mass.: Massachusetts Institute of Technology.

Desmedt, E. (2014). De impact van de performance audits van het Rekenhof. Survey bij ambtenaren van de federale overheid. Masterproef aangeboden tot het verkrijgen van de graad van Master of Science in het Overheidsmanagement en -Beleid, KU Leuven.

INTOSAI (2013). ISSAI 300 - Fundamental Principles of Performance Auditing. Vienna: INTOSAI.

Kirkhart, K.E. (2000). Reconceptualizing evaluation use: an integrated theory of influence. Directions for Evaluation, 88, pp. 5-22.

Leeuw, F. L. (1996a). Audit des performances, nouvelle gestion publique et amélioration des performances : questions et défis. In Audit des performances et modernisation de l'administration, OCDE, pp. 115-126. Paris : OCDE.

Leeuw, F. L. (1996b). Auditing and Evaluation : Bridging a Gap, Worlds to Meet ?. In Evaluation and Auditing : Prospects for Convergence, Carl Wisler (éd.), pp. 51-60. San Francisco : Jossey-Bass Publishers.

Leeuw, F. L. (1997). Is auditing a "trust killer" and can the public sector better do without it?. Paper for the conference 'The management of durable relations: theoretical and empirical models for households and organizations', Utrecht University, 26-28 juin.

Leeuw, F. L. (2006). Over impact en neveneffecten van performance monitoring en auditing. VTOM, 4, pp. 36-44.

Lonsdale, J. (1999). Impact. In Christopher Pollitt, X. Girre, J. Lonsdale, R. Mul, H. Summa \& M. Waerness (Red.), Performance or Compliance? Performance Audit and Public Management in Five Countries (pp. 171-193). Oxford: Oxford University Press.

Malloy, J. (2004). An auditor's best friend? Standing committees on public accounts. Canadian Public Administration / Administration publique du Canada, 47 (2), pp. 165-183.

Morin, D. (2000). La vie après une mission de vérification de l'optimisation des ressources: le point de vue des gestionnaires (Life after value for money audit: managers' point of view). Administration publique du Canada/Canadian Public Administration, 43 (4), pp. 432-452,

Morin, D. (2001). Influence of Value for Money Audit on Public Administrations: Looking Beyond Appearances. Financial Accountability \& Management in Governments, Public Services and Charities, 17 (2), pp. 99-117.. 
Morin, D. (2008). Auditors general's universe revisited: an exploratory study of the influence they exert on public administration through their value for money audits, Managerial Auditing Journal (UK), 23 (7), pp. 697-720.

Morin, D. (2014). Auditors general's impact on Administrations: A pan-Canadian study (20012011), Managerial Auditing Journal (UK), 29 (5), pp. 395-426.

Morin, D. (2015). Parliamentarians' relations with the Auditor General of Canada during Sheila Fraser's mandate (2001-2011). In Making Governments Accountable, Zahirul Hoque, ed. Routledge: Chapter 4, May.

Morin, D. , Hazgui, M. (Forthcoming 2016). We are much more than watchdogs: The dual identity of auditors at the UK National Audit Office, Journal of Accounting \& Organizational Change.

Parker, L. D. (1986). Value-for-Money Auditing: Conceptual, Development and Operational Issues. Caufield (Victoria): Australian Accounting Research Foundation, 92 p.

Pollitt, C, Girre X., Lonsdale J., Mul R., Summa H. and Waerness. M. (1999). Performance or Compliance? Performance Audit and Public Management in Five Countries, Oxford University Press, Oxford.

Pollitt, C. (2006). Performance information for democracy: the missing link? Evaluation, 12(1), pp. $38-55$.

Raudla, R., Taro, K., Agu, C. \& Douglas, J.W. (2015). The impact of performance audit on public sector organizations: the case of Estonia. Public Organization Review, march.

Rekenhof (n.d.). Bevoegdheden. Geraadpleegd via

https://www.rekenhof.be/NL/Voorstelling/Bevoegdheden.html

Rekenhof (2004). Missieverklaring. Geraadpleegd via

https://www.rekenhof.be/NL/Voorstelling/VisieEnWaarden.html\#Missieverklaring

Rekenhof (2011). Synthese van normen uit doelmatigheidsonderzoeken (1998-2011) intern document

Reichborn-Kjennerud, K. (2013). Does Performance Auditing Matter? The Government Administration's Response to the Performance Auditing of the Norwegian Office of the Auditor General. Thesis for the degree of philosophiae doctor (PhD), University of Bergen, Norway.

Smith, P. (1993). "Outcome-Related Performance Indicators and Organizational Control in the Public Sector.” British Journal of Management, 4, pp. 135-151.

Smith, P. (1995). "On the Unintended Consequences of Publishing Performance Data in the Public Sector.” International Journal of Public Administration, 18 (2-3), pp. 277-310.

Sterck, M. (2007). Impact of performance audit. In V. Conings, M. Sterck \& G. Bouckaert (Red.), Budgeting, Accounting and Auditing for Results - Towards Integrated Financial Management (pp. 95-123). Leuven: Steunpunt Bestuurlijke Organisatie Vlaanderen. 
Van Acker, W. et al. (2014). Mapping and Analyzing the Recommendations of Ombudsmen, Audit offices and Emerging Accountability Mechanisms. Research Report no. 3 of the LIPSE Project. (http://www.lipse.org/publications/type/Research\%20reports)

Van Loocke, E. \& Put, V. (2010). De impact van performance auditing: "slow and subtle"?. In D. Verlet \& C. Devos (Red.), Efficiëntie en effectiviteit van de publieke sector in de weegschaal (pp. 187-220 ). Brussel: Studiedienst van de Vlaamse Regering.

Van Loocke, E. \& Put, V. (2011). The impact of performance audits: a review of the existing evidence. In J. Lonsdale, P. Wilkins \& T. Ling (Red.), Performance Auditing. Contributing to Accountability in Democratic Government (pp. 175-208). Cheltenham, UK - Northampton, MA, USA: Edward Elgar.

Van Loocke, E. (2013). Performance auditing. De impact van performance audits. Presentatie in het kader van de Masterclass Overheidsauditor van de Antwerp Management School.

Weets, K. (2011). Impact at local government level: a multiple case study. In J. Lonsdale, P. Wilkins \& T. Ling (Red.), Performance Auditing. Contributing to Accountability in Democratic Government (pp. 248-267). Cheltenham, UK - Northampton, MA, USA: Edward Elgar.

Weiss, C. (1977). Research for policy's sake: the enlightenment function of social science research. Policy Analysis, 3(4), pp. 531-545.

Widmer, T. \& Neuenschwander, P. (2004). Embedding Evaluation in the Swiss Federal Administration: Purpose, Institutional Design and Utilization. Evaluation, 10(4), pp. 388-409. 